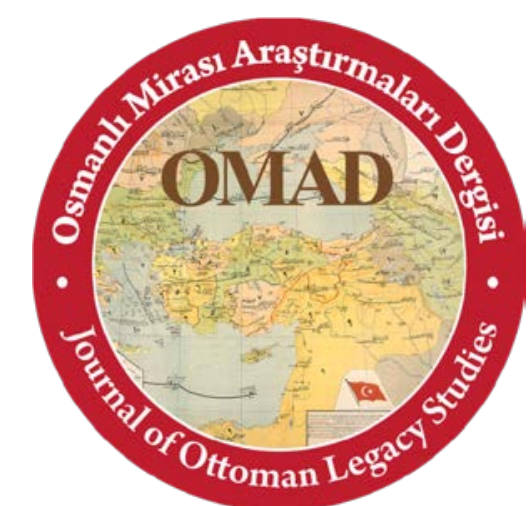

Osmanlı Mirası Araştırmaları Dergisi/Journal of Ottoman Legacy Studies

ISSN 2148-5704

www.osmanlimirasi.net

osmanlimirasi@gmail.com

Cilt 6, Sayı 14, Mart 2019 / Volume 6, Issue 14, March 2019

\title{
ON THE TÂRÎH-İ NIŞÂNCI PAŞA (LIT. THE HISTORY OF NİŞÂNCI PAŞA) OF RAMAZÂN-ZÂDE AND ITS COPIES
}

Ramazân-zâde'nin Târîh-i Nişâncı Paşa İsimli Eseri ve Nüshaları Üzerine

Makale Türü/Article Types : Araştırma Makalesi/Research Article

Geliş Tarihi/Received Date : 19.01.2019

Kabul Tarihi/Accepted Date : 04.02.2019

Sayfa/Pages : 225-241

DOI Numaras1/DOI Number : http://dx.doi.org/10.17822/omad.2019.121

\section{RUKIYYE ÖZDEMIR}

(Dr.), e-mail: demeter_2709_@hotmail.com, ORCID: https://orcid.org/0000-0002-2328-8989

\section{Atıf/Citation}

Özdemir, Rukiye, "On the Târîh-i Nişâncı Paşa (Lit. The History of Nişâncı Paşa) of Ramazan-zâde and Its Copies", Osmanlı Mirası Araştırmaları Dergisi, 6/14, 2019, s. 225-241.

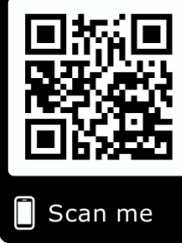





\title{
ON THE TÂRîH-İ NIŞÂNCI PAŞA (LIT. THE HISTORY OF NiŞÂNCI PAŞA) OF RAMAZÂN-ZÂDE AND ITS COPIES*
}

\author{
Ramazân-zâde’nin Târîh-i Nişâncı Paşa İsimli Eseri ve Nüshaları Üzerine \\ RUKIYE ÖZDEMIR
}

\begin{abstract}
A statesman and a historian, Ramazân-zâde Nişâncı Mehmed Paşa had been working as the secretary of the dîvan (lit.Imperial Council or Supreme Court), provincial treasurer, head of secretaries, and ultimately as a nişânc1 (member of the dîvan responsible for the signatures of the sultan being stamped on the decrees) Although its exact date is not precisely known, either before or during his divan membership task, he compiled a summary general history titled with his own name. Târih-i Nişâncı Paşa was comprised of an introduction, four chapters and an epilogue. The first chapter is the history of the prophets starting from the Prophet Adam until the Prophet Muhammad. The pieces of information in this chapter, which discusses the history of the prophets, are in the form of anecdotes. These anecdotes were written after being compiled from the most reliable narratives. The second chapter is comprised of pieces of information concerning the Prophet Muhammad, Rashidun Khalifas, and the emperors of the Umayyads, Abbasids, Fatimid Empire, Ayyubids, and Mamelukes. This chapter was designed in a way to include the genealogical information of the emperors such as date of birth, death, and the duration of their reigns. Moreover, even with simple sentences, the most notable personalities of each period, their works, and important aspects were touched on. The third chapter is comprised of the political events starting from the foundation of the Ottoman State until the murder of Bayezid, the son of Suleiman the Magnificent. The fourth chapter mentions about Pisdadi, Keyani, Eskani, Sassanids, Greeks, and Romans, which are named as other states. In this study, a general introduction of Ramazân-zâde Nişâncı Mehmed Paşa and his Târih-i Nişâncı Paşa was given, aiming to reveal author and the identification of his writing. The basic sources of the research are comprised of manuscripts provided from the domestic and international collections.
\end{abstract}

Keywords: Ottoman Historiography, Ramazân-zâde, Târîh-i Nişâncı Paşa

Öz: Ramazân-zâde Nişâncı Mehmed Paşa, Osmanlı Devleti’nde divan katipliği, defterdarlık, reisülküttaplık ve nihayetinde nişancılık yapmış devlet adamı ve tarihçidir. Tarihi kesin olarak bilinmemekle birlikte nişancılık vazifesi öncesi veya sırasında kendi adıyla anılan muhtasar bir umumi tarih telif etmiştir. Târih-i Nişâncı Paşa bir mukaddime, dört bölüm ve bir hatimeden oluşmaktadır. Birinci bölüm Hz. Âdem'den Hz. Muhammed'e kadar gelen peygamberler tarihidir. Peygamberler tarihinin anlatıldığ 1 bu bölümdeki bilgiler kıssalar şeklindedir. Bu kıssalar en çok kabul gören rivayetlerden derlenerek yazılmıştır. İkinci bölüm Hz. Muhammed, Dört Halife, Emevi, Abbasi, Fatımi, Eyyubi ve Memlük devletlerinin hükümdarlar bilgisinden oluşmaktadır. Bu bölümde devlet hükümdarları tamamen şecere esaslı doğum ve ölüm tarihleri ile toplam saltanat süreleri şeklinde düzenlenmiştir. Ayrıca aralarda her dönemin en tanınmış şahsiyetlerin eserleri ve önem arzeden yönleri birer cümlecik de olsa belirtilmiştir.Üçüncü bölüm Osmanlı Devleti'nin kuruluşundan Kanuni Sultan Süleyman'ın oğlu Bayezıd'ın öldürülmesine kadar siyasi olayları teşkil etmektedir. Dördüncü bölüm ise diğer devletler olarak adlandırılan Pîşâdî, Keyânî, Eşkânî, Sâsânî, Batlamyus, Yunan ve Romalılardan bahsetmektedir. Bu çalışmada Ramazân-zâde Nişânc1 Mehmed Paşa ve Târih-i Nişâncı Paşa adlı eserin genel tanıtımı yapılarak müellif ve eserin kimliğinin ortaya çıkarılması hedeflenmiştir. Araştırmanın temel kaynaklarını yurt dışı ve yurt içi kütüphanelerinden tedarik edilen yazma eserler oluşturmaktadır.

Anahtar Kelimeler: Osmanlı Tarih Yazıcılığı, Ramazân-zâde, Târîh-i Nişâncı Paşa

\footnotetext{
* This article was derived from the doctoral thesis titled "Critique of Text and Analysis of the Târîh-i Nişâncı Paşa of Ramazân-zâde” conducted in the Atatürk University, Institute of Turkic Studies, History Department.
} 


\section{Life of Ramazân-zâde}

Nişâncı Mehmed Paşa was a statesman and a historian during the reign of the Suleiman the Magnificent. No information was found concerning the birth date of the author neither in archives nor in sources.

Although there is no information about the first years of Nişâncı Mehmed Paşa, it is known that he was from Merzifon ${ }^{1}$. He was the father of Ahmed Efendi, who served as the kadi of Mecca, Egypt, and Medina. Moreover, he was the grandfather of a $17^{\text {th }}$ century historian, Mehmed Kudsî, who served as the kadi of Mecca, Medina, Egypt, Thesselonike, Bursa, and Istanbul, and who was the author of Mir'at-1 Kâ'inât. ${ }^{2}$

When he was a student at a madrasah, Ramazân-zâde was known with the "Greenish" nickname. ${ }^{3}$ In order to be differentiated from his colleague and contemporary as well as a historian and a member of the divan, Celâl-zâde Mustafa Çelebi, he rose to prominence with the title "Küçük Nişâncı(lit. The Little Nişâncl)". ${ }^{4}$ He was called as "Ramazân-zâde (lit. The Son of Ramazan)" because of his father. ${ }^{5}$

Following his education in the madrasah, the author had respectively served as the Secretary of Dîvan (Imparial Council) and the head of the provincial treasurers in 1553 A.D. (960 Hijri). Ramazân-zâde Mehmed Paşa served as the head of secretaries ${ }^{6}$ in 1554 (961 Hijri), afterwards, he conducted the land registration in the Morea province. Owing to his success in this task, he was awarded the nişânc1 position. ${ }^{7}$ It is accepted that his first employment as a nişâncı was 1557-1558 (965 Hijri). ${ }^{8}$ After being dignified as a nişâncı, Ramazân-zâde was started to be called as "Paşa" and "Tevkî (lit. Stamp of the Sultan on the Decrees)" .

\footnotetext{
${ }^{1}$ Bursalı Mehmed Tahir, Osmanlı Müellifleri, Cilt III, Meral Yay.,İstanbul 1975, s. 119; Mehmed Cemâleddîn, in his Osmanlı Tarih ve Müverrihleri-Âyine-i Zurefâ, gave the information that he was from Merzifon as follows: "Abovementioned person had become known in the Merzifon district in Anatolia". See. Mehmet Arslan, Mehmed Cemâleddîn, Osmanlı Tarih ve Müverrihleri-Âyine-i Zurefâ, Kitabevi Yay., İstanbul 2003, p. 42. ; Similarly, Ahmed Resmi Efendi, in his Halifetü'r-Rüesâ presented the same information as such: "He is known to be from Merzifon in the Anatolia province”. See. Ahmed Resmi Efendi, Halifetü'r-Rüesâ, İstanbul 1269, p. 7.

2 Orhan Bayrak, Osmanlı Tarihi Yazarları, Milenyum Yay., İstanbul 2002, s.296; Abdülkadir Özcan, "Mehmed Çelebi- Ramazan-zâde”, Diyânet İslâm Ansiklopedisi, Türkiye Diyânet Vakfi Yay., İstanbul 2003, XXVIII, p.450; Mehmed Cemâleddîn, in his Osmanlı Tarih ve Müverrihleri-Âyine-i Zurefâ, the author introduced him as follows: "Ahmed Efendi, the venerable son of Ramazân-zâde Mehmed Efendi who was assigned to dîvan membership during the reign of Suleiman the Magnificent and known with his book "Muhtasar Tarih/Summary History", was assigned as a kadi in the peripheries in 1555, in Mecca in 1563, and in Egypt in 1566, and in Medina in 1578. Ahmed Efendi, who was the bright son of Ramazan-zâde, wise, scholar, and an intellectual, died while he was the kadi of Medina in 1578. His grave is in Damascus.” See. M. Arslan, ibid., p. 42.

${ }^{3}$ A.Özcan, ibid., p. 449.

${ }^{4}$ O.Bayrak, ibid., p. 280.

5 In the Osmanll Tarih ve Müverrihleri-Âyine-i Zurefâ of Mehmed Cemâleddîn and in the Halifetü'r-Rüesâ of Ahmed Resmi Efendi, he was mentioned as follows: "He became known with the name Ramazân-zâde and he was highly honored like the sacred Ramadan month. See. M. Arslan, ibid.,. p. 42; See. R. Efendi, ibid., p. 7.

${ }^{6}$ Mehmed Süreyya, Sicil-i Osmanî, Volume III, Tarih Vakfi Yurt Yay., İstanbul 1996, p. 968.

${ }^{7}$ Bekir Sitkı Baykal, Peçevi Tarihi Volume 1, Kültür Bakanlığı Yay., Ankara 1999, p. 47.

${ }^{8}$ M. Süreyya, ibid., p. 968; in his Osmanlı Tarih ve Müverrihleri-Âyine-i Zurefâ, Mehmed Cemâleddîn wrote as follows: "He was assigned in 1557 as the dîvan member who was responsible for putting the sultan's signature on the decrees decided in the dîvan of the Ottoman State" See. M.Arslan, ibid., p. 42; And while mentioning about the names of the dîvan members of the Suleiman the Magnificent reign in his Nev'î-zâde Atâyî Zeyl-i Şakâ'ik he introduced Ramazân-zâde as such: "Ramazân-zâde: in the year 965 (1557 A.D.)." See. Suat Donuk, Hadâiku'lhakâ'ik fî Tekmileti'ş-Sakâ'ik, Nev 'î-zâde Atâyinin Şekâ'ik Zeyli,Inceleme-Tenkitli Metin, Edt. Derya Örs, Türkiye Yazma Eserler Kurumu Başkanlığı, İstanbul 2017, Volume I, p. 476; Similarly, the 965 Hijri date was mentioned in the Halifetü'r-Rüesâ of Ahmed Resmi Efendi as follows: "After managing the land registration in Morea province, he was granted the nişânc1 position in the year 965 (Hijri)". See. R.Efendi, ibid., p. 7.

9 A.Özcan, ibid., p. 450; İbrahim Peçevî Efendi used the statement "Tevkî‘ Ramazân-zâde” for Ramazân-zâde. See.İbrahim Peçevi, Peçevi Tarihi, University Of Toronto, Printed Transcript Nr. DR 511 P33 V. 1, p. 2.
} 
After performing the nişâncı task, Ramazân-zâde was assigned as the director of title deeds, probably as a result of a plot of his rivals. Afterwards, he was assigned as the ArabianPersian provincial treasurer in Aleppo, and subsequently he was assigned as a sanjak seigniorate (governor of several cities) in Egypt. ${ }^{10}$

Since the nişâncı position was vacant when Nişâncı Mehmed Paşa was being assigned to Egypt, Suleiman the Magnificent ordered Ramazân-zâde to come from Egypt for this position. However, Rüstem Pasha, the grand vizier who was an opponent of Ramazân-zâde, mentioned to the Sultan that Ramazân-zâde went to Egypt with his own will. ${ }^{11}$ Ignoring the statement of his grand vizier, ${ }^{12}$ the Sultan ordered for the arrival of Ramazân-zâde to Istanbul and he was assigned as nişâncı for the second time in 1562 (969 Hijri) ${ }^{13}$. However, after a while, the author retired in 1562 (970 Hijri) with a fee of 50.000 Ottoman coins. ${ }^{14}$

A consensus cannot be reached about the author's date of death. Peçevî İbrahim Efendi doesn't give any information about the date of death of Ramazân-zâde in his book, ${ }^{15}$ while the accepted common view is that Ramazân-zâde died in Cemaziyelevvel (the fifth lunar monthOctober 1571) 979 Hijri in his home in Fatih/Istanbul. ${ }^{16}$ The grave of Ramazan-zâde was within the Emîr Buhârî Tekkesi burial area outside the Edirnekapı walls in Istanbul, but it was collapsed due to the belt highway built later. ${ }^{17}$

\section{Târîh-i Nişâncı Paşa}

\subsection{The Name of the Book}

As far as it's understood from the copies that were examined, the name of the book varies. The book, particularly in some of its copies in Turkey, was named as "Siyer-i Enbiyâ-i 'İâm ve Ahvâl-i Hulefâ-yı Kirâm ve Menâkıb-ı Âl-i Osmân (lit. The History of Prophets and the Khaliphas and the Ottoman History)", ${ }^{18}$ in some other copies it is named as "Târîh-i Müntehâbü'l-Fehmi'l-akrâb (lit. The Distinguished and the most Comprehensible History)", ${ }^{19}$

${ }^{10}$ A.Özcan, ibid., p. 450; "Ramazân-zâde Mehmed is a famous wise person with distinguished features among the ulema (pundits), he once worked as a bureaucrat, in another time served as the head of secretaries. Afterwards, he conducted the land registration of the Morea province, due to his success in this task, he was assigned as a dîvan member. Afterwards, he was assigned as a provincial treasurer, serving as the Afterwards, he was assigned as the Arabian-Persian provincial treasurer, and subsequently assigned as a sanjak seigniorate (governor of several cities) in Egypt." See. İ.Peçevi, ibid. p. 44.

11 "the grandvizier, with his own will", See. İ. Peçevi, ibid., p. 44.

12 "Ignoring his grand vizier, Suleiman the Magnificent said: ' It is a-not appropriate to send wise men from our government to Egypt. What appropriate is to bring such wise and intellectual individuals from Egypt or other provinces to the capital', and he ordered transfer of Ramazân-zâde from Egypt to Istanbul, assigning him again to the dîvan membership." See. İ. Peçevi, ibid., p. 44.

13 "I assigned Mehmed, who once conducted the registration of Morea, to the dîvan membership" See. İ.Peçevi, ibid., p. 44.

${ }^{14}$ In his Osmanlı Tarih ve Müverrihleri-Âyine-i Zurefâ, Mehmed Cemâleddîn mentioned in such a sentence: "he retired in 1562 with a fee of 50.000 Ottoman coins,”. See. M.Arslan, ibid., p. 42; And in his Nev'î-zâde Atâyî Zeyli Şakâ'ik he reported: "Instead of Ramazan-zâde, who once served as a dîvan member, he was assigned as dîvan member in 970 (Hijri)”. See. S. Donuk, ibid., p. 369.

15 "Afterwards he retired and began to perform his five time prayers in the Sultan Mehmed Mosque. In this while he died. He wrote a summary history book. This summary history book was distinguished and respected among other important history books and it became famous”. See. İ. Peçevi, ibid. p. 44.

${ }^{16}$ A.Özcan, ibid., p.450; In his Osmanlı Tarih ve Müverrihleri-Âyine-i Zurefâ, Mehmed Cemâleddîn recorded. "He died in October nine hundred seventy nine (Hijri). May God rest his soul.”. See. M. Arslan, ibid., p. 42; In his Keşfü'z-zunûn, Katip Çelebi introduced him and his book as follows: "The history book of Nişâncı Ramazân-zâde Muhammad: This personage died in nine hundred seventy nine $(979 \mathrm{H})$ and this book is Turkish, it is short.". See. Rüştü Balc1, Keşfü'z-Zunûn, An Esâmi'l-Kütübî ve'l-Fünûn (Clearing the air About the Names of Book and Sciences), Volume I, Tarih Vakfi Yurt Yay., İstanbul 2007, p. 275.

${ }^{17}$ O.Bayrak, ibid. p. 296.

${ }^{18}$ Süleymaniye Library Ali Emiri Efendi Section Nr. 00585.

${ }^{19}$ Süleymaniye Library Esâd Efendi Section Nr. 02172, Süleymaniye Library Hacı Mahmud Efendi Section Nr. 04857, France, Bibliotheque nationale de France Nr. Turco 96, Unıversity of Toronto Library Nr. Dr.481/M.1873. 
while in some others as "Tevârîh-i Nișânî (lit. The History of Nișancl), Siyer-i Enbiyâ-i 'İâm ve Hülafâ-i Kirâm (lit. The History of Prophets and Khalifas), Menâkıb-ı Selâtîn Âl-i Osmân ve Gazevât-ı Hayrâtü'l-îş̧ân (lit. The History of the Ottoman State Warfare and History of Charities)", ${ }^{20}$ and in other copies it was named as "Müntehâbü'l-Fehmi'l-akrâb (lit. The Distinguished and the most Comprehensible History), Siyer-i Enbiyâ-i 'İzâm ve Hülafâ-i Kirâm (lit. The History of Prophets and the Khaliphas), Menâkıb-ı Selâtîn Âl-i Osmân ve Gazevât ü Hayrât-lîşân (lit. The History of the Ottoman State Warfare and History of Charities), Tevârîh-i Şâhân-ı Pîşîn ve Mülûk-ı Mukaddimîn (lit. The Distinguished and the most Comprehensible History and Introduction to the History of Other States)". ${ }^{21}$ In its copies found in international collections, it is named generally as "Târîh-i Nişâncı Paşa(lit.The History of Nişancı Pasha)". The most important factor in this issue is the fact that the author had been assigned as a nişânc1 for several times. Only the copies in the National Library of Cairo/Egypt are named as "Subhatü'l-Ahyâr (lit. Rosary of the Charities)". The name of the book in this study was accepted as Târîh-i Nişâncı Paşa. The main motive behind this acceptance is that this book has gained recognition with this name.

\subsection{Publication Reason and Date of the Book}

Ramazân-zâde was contended with explaining the motive behind writing this book in general statements including the reasons within the introduction section. According to him, there were three main factors in writing this book. The first factor was that Suleiman the Magnificent attached importance to science and knowledge and supported scientists ${ }^{22}$. It was also effective for the author in writing this book that Suleiman the Magnificent believed in that investigating and making research on history for learning and analyzing the lives of previous sultans was a necessity ${ }^{23}$. Moreover, the author accepted it as a principle for himself that Suleiman the Magnificent believed in that it was only possible to maintain the existing fame with the knowledge in history ${ }^{24}$.

As the second factor, it can be accepted that he was assigned as a nişâncı by the Suleiman the Magnificent and his intention to write with a distinguished style, as he was good at repartee during his employment. ${ }^{25}$

The third factor was the intention of the author to write important achievements of previous periods. Additionally, he believed that transferring the events and characteristics of the past communitites to the future was only possible by writing. ${ }^{26}$

It was mentioned before that the Târîh-i Nişânc1 Paşa was written as a summary. Ramazân-zâde listed the reasons to write in this style as simply preserving, and to tell without being boring and causing tiredness. ${ }^{27}$ It can even be mentioned that he wrote the book as a handbook owing to these reasons.

Although the author doesn't provide any information concerning the style he used in the book, it is possible to observe clues. In fact, these are among the clues mentioned in the book that it took a long time to publish, it was tiring, and it was written due to getting bored of particularly his environment and events. ${ }^{28}$

\footnotetext{
${ }^{20}$ Süleymaniye Library Âli Emîri Efendi Section Nr. 00585, Süleymaniye Library Hâcı Mahmud Efendi Section Nr. 04822, France, Bibliotheque nationale de France. Nr. Turco 96, University of Toronto Library Nr. Dr.481/M.1873.

${ }^{21}$ Süleymaniye Library Esad Efendi Section Nr. 02186.

${ }^{22}$ Ramazân-zâde, Târîh-i Nişâncı Paşa, Ms.or.fol.4153, Vr. 3a.

${ }^{23}$ Ramazân-zâde, ibid., Vr. 3a.

${ }^{24}$ Ramazân-zâde, ibid., Vr. $3^{a}$.

${ }^{25}$ Ramazân-zâde, ibid., Vr. 3a.

${ }^{26}$ Ramazân-zâde, ibid., Vr. $2^{\text {b. }}$.

${ }^{27}$ Ramazân-zâde, ibid., Vr. 3a.

${ }^{28}$ Ramazân-zâde, ibid., Vr. $3^{\mathrm{a}}$.
} 
Although Ramazân-zâde mentioned with explanations the motive behind writing the book, he didn't give any information concerning its date of publication. In the studies conducted on resources and archives, no information was reached concerning the date of publication. Therefore, the issue was attempted to be clarified by discussing two assumptions concerning the date of its publication. Based on his remarks ${ }^{29}$ that emphasize being "good at repartee" in order to represent the nişânc1 position in the best manner, the first assumption is the thought that Ramazân-zâde wrote this book during his first assignment between 1557-1558 (965 Hijri). The second assumption, based on again his remarks ${ }^{30}$, is that he mentioned that it took too much time to publish this book and it was tiring, from this point forth, he probably wanted to serve as a nişânc1. Therefore, it can be thought that this book was probably written before the years 1557-1558.

There is no information not only about the publication date of the book, but also about the date of its completion, neither in the book nor in other sources. However, an interpretation can be made under the light of existing information. Firstly, the death date of Ramazân-zâde is known as 1571 (979 Hijri). The first known copy of the book was dated as 1568 (976 Hijri). Suleiman the Magnificent died in 1566. Ramazân-zâde wished a long life for the sultan in the epilogue of the book with a prayer-like statement "May our Sultan be everlasting in his blessed throne and with his loyal servants in the caliphate position" ${ }^{\prime 31}$. All of these pieces of information support the idea that the author completed the book before the death of Suleiman the Magnificent.

\subsection{The Content of the Book}

Besides the tradition of writing Tevârih-i Âl-i Osmâns (lit.The History of the Ottoman Dynasties), which were started to be used since the reign of the Sultan Murat II, there are numerous books which were compiled as general history. Although the general history books have almost the same content in the general sense, there are differences in the presentation styles of their contents. While some of the general history pieces present their contents in a more detailed style, some others prefer to present their contents rather in a summary-extract style in a chronological manner. Similarly, Târîh-i Nişâncı Paşa of Ramazân-zâde was a summary general history, which was written in a chronological manner.

According to the information obtained from the Târîh-i Nişâncı Paşa copies, which have the preface part, the book was committed to the paper within a certain classification and program. Within the framework of the developed plan, and as is understood from the content, the book is comprised of an introduction, four chapters, and an epilogue.

In the introduction chapter, praises and thanks were offered to the God and prayers were made for the prophets. The importance of knowledge was touched upon, discussing the necessity to build artifacts in order to draw lessons from the past experiences. The points taken into consideration and the reasons of its publication were mentioned in general statements. In addition to this, the sources used in writing the book were mentioned briefly. ${ }^{32}$

The first chapter, titled as "Tevârîh-i Meşâhîr-i Enbiyâ-i 'İâm (lit.The History of the Grand and Famous Prophets) is the history of the prophets starting from the Prophet Adam until the Prophet Muhammad. The most remarkable point in this chapter is that general

\footnotetext{
29 "This book, which was created during the nişâncı task of the sultan and benefited from previous history books, was written to be repartee in answering questions and to respond in an outstanding and favorable way.” See. Ramazânzâde, ibid., Vr. 3ª.

30 "Too much time was spent and it was tiresome to write all chapters of the book from the beginning to the end. Therefore, it was avoided from being wordy. It was because telling the events in a wordy way tires people and renders them weak. Therefore, the book was written as a summary.” See.Ramazân-zâde, ibid., Vr. 3a.

31 "May God render eternal the sultanate and caliphate position of the Sultan and prolong his life" See. Ramazânzâde, ibid., Vr. 124b.

${ }^{32}$ Ramazân-zâde, ibid., Vr. $1^{\text {b-3 }}{ }^{\mathrm{b}}$.
} 
information was given about the prophets without entering into details. ${ }^{33}$ Moreover, the author narrated anecdotes about the prophets as a summary. Additionally, he discussed the professions of each prophet within compendiums. ${ }^{34}$

In the second chapter, under the title "Vilâdet-i bâ-Sa 'âdet-i Hazret-i Muharrem-i Harem lî-ma 'Allah (lit.Prophet Muhammad, who was born in the blissed Muharram month)", initially general information was given about the Era of Bliss (lit.The time period under the reign of the Prophet Muhammad). Afterwards, pieces of genealogical information were given such as date of birth, death, and the duration of the reigns of the Rashidun Khalifas, and the emperors of the Umayyads, Abbasids, Fatimid Empire, Ayyubids, Mamelukes, and Circassian states. Moreover, even with simple sentences, the most notable personalities of each period, their works, and important aspects were touched on. ${ }^{35}$

The most important and the most voluminous part of the book is the third chapter. This chapter, titled as "Menâkıb-ı Selâtîn-i Âl-i 'Osmân ve Gazevât ü Hayrât-î̧̧ân. Takdîm-i Zikr-i Ensâb ve Takhîm-i Emrü'n-Nesâb (lit. The History of the Ottoman State Warfare and History of Charities Introduction and explanation of lineages and families)", was allocated for the Ottomans, and majority of this chapter was comprised of the era of the Suleiman the Magnificent. Since the book was written as a summary-extract, in the Ottoman History chapter, the dates of birth and death, children, grand viziers, holy wars, charities and benefactions of each sultan were briefly mentioned, including the ulema (lit.pundits), sheiks, statesmen, and their works. This chapter was ended with the political murder of Bayezid, the son of Suleiman the Magnificent, in Kazvin. ${ }^{36}$

In the epilogue part, it was mentioned that the author was grateful to the Suleiman the Magnificent owing to his good and beneficent deeds, praying and making a wish for him to live long. ${ }^{37}$

The last chapter of the book, under the title "Tevârîh-i Şâhân-ı Pîşîn Ve Mülûk-ı Mukaddimîn. (lit. The Distinguished and the most Comprehensible History and Introduction to the History of Other States )". Elkāb-ı Selâtîn-i 'Âlî-Cenâb ( lit.The nicknames of grand sultans)", the author gave small pieces of information about Kaiser, Kisra, Keyani, Eskani, Sassanids, Ptolemies, Greeks, and Roman Empire, which we can name as other states. These pieces of information were generally genealogical and chronological listings. ${ }^{38}$

\subsection{Copies of the Book}

There are seventy-six domestic and forty international manuscript copies of Târîh-i Nişâncı Paşa that could survive until today. However, it cannot be mentioned that these are the final figures.

It is possible to examine the copies of the book after classifying them into three groups. The first group is comprised of the copies that have the "preface parts". ${ }^{39}$ In the copies in this

\footnotetext{
${ }^{33}$ Ramazân-zâde, ibid. Vr. $3^{\text {b- }}$ 15b.

${ }^{34}$ Bk. Ramazân-zâde, ibid., Vr. 16ª, Vr. $16^{\text {b }}$.

${ }^{35}$ Ramazân-zâde, ibid., Vr. 14a-40ª

${ }^{36}$ Ramazân-zâde, ibid., Vr. 41 ${ }^{\mathrm{a}}-122^{\mathrm{b}}$.

${ }^{37}$ Ramazân-zâde, ibid., Vr. $122^{\mathrm{b}}-126^{\mathrm{a}}$.

${ }^{38}$ Ramazân-zâde, ibid., Vr. $126^{\mathrm{a}}-134^{\mathrm{b}}$.

${ }^{39}$ France, Bibliotheque nationale de France Nr. Turco 96, University of Toronto Library Nr. Dr.481/M.1873, SL. Âli Emîri Section Nr. 01011, SL. Çelebi Abdullâh Section Nr. 00242, SL. Esad Efendi Section Nr. 01803-005, SL. Esad Efendi Section Nr. 02172, SL. Esad Efendi Section Nr. 02185, SL. Esad Efendi Section Nr. 02186, SL. Hac1 Mahmud Efendi Section Nr. 04857, SL. Hâlet Efendi Section Nr. 00036/008, SL. Murad Molla (M. Arif Efendi) Section Nr. 00184, SL. Nuru Osmaniye Section Nr. 03159, SL. Pertevniyal Section Nr. 00835/002, SL. Reşid Efendi Section Nr. 00617, SL. Reşid Efendi Section Nr. 00634, TPM. Bağdat Section Nr. B.195, TPM. Medine Section Nr. M.526, TPM. Revân Section Nr. R.1128,TPM. Revân Section Nr. R.1130, TPM. Revân Section Nr. R.1132, SHML. Nr. 497, Kastamonu City Public Library Nr. 37 Hk. 2364/1 ], Kastamonu City Public Library Nr.
} 
groups, there is a 16-line long content including the name and the chapters of the book. In addition to this, it is also mentioned that the book is written by the author benefiting from the previous books. Afterwards, stating that the advices of smart elderly are written enough, thus, the beneficial pieces of information are gathered in this book. As the evaluation of the information given in this content, it was considered that this part should be the preface, which is used as a criterion in the classification. The second group is comprised of the copies that "do not have preface part". ${ }^{40}$ The majority of the copies are in this group. The third group is comprised of copies with "addendums". ${ }^{41}$ In the copies of this group, after the fourth chapter that mentioned about the other states, the campaigns of the era of Suleiman the Magnificent were written under the title "The Fourteenth Campaign", which particularly mentioned about the developments during and after the Szigetvar campaign, the demise of Suleiman the Magnificent, and accession of the Selim II to the throne. Through the examined copies, and based on the fact that, after the "Fourteenth Campaign" content, the language and expression were differentiated and systematical writing was disrupted, it was considered that this part was the addendum. Therefore, a third group was created as copies with addendums.

\subsubsection{Copies Found in International Collections}

The copies found in the libraries abroad are as follows:

\begin{tabular}{|l|l|l|}
\hline Collection that Contains the Copy & Archive Number & Copy Date Hijri/A.D. \\
\hline USA Harvard University Houghton Library & Nr. Ms. Turk. 8. & ? \\
\hline France, Bibliotheque nationale de France. & Nr. Turco 100. & $996 / 1587$ \\
\hline France, Bibliotheque nationale de France. & Nr. Turc 1131. & $1090 / 1679$ \\
\hline France, Bibliotheque nationale de France. & Nr. Turc 191. & $1057 / 1647$ \\
\hline France, Bibliotheque nationale de France & Nr. Turc 1319. & $1073 / 1662$ \\
\hline France, Bibliotheque nationale de France. & Nr. Turco 95. & $1041 / 1631$ \\
\hline France, Bibliotheque nationale de France. & Nr. Turco 96. & $982 / 1574$ \\
\hline
\end{tabular}

37 Hk 1962, Diyarbakır City Public Library Nr. 845, İzmir National Library Nr. 928, İBL. Nr. 5268 / 38, İBL. Veliyüddin Section Nr. 2403, Ankara National Library Nr. 06 Mil Yz. A.45, Ankara National Library Nr.06 Mil Yz. 3035/1, Ankara National Library Nr.06 Mil Yz. 3164, Ankara National Library Nr. 06 Mil Yz. A.3261, Bursa İnebey Manuscript Library Nr. HO.1085., Ankara Turkish Historical Society Library, Nr. Y / 0079-1.

${ }^{40}$ Germany Staatsbibliothek, Berlin, Ms.or.fol.4153, Germany Staatsbibliothek, Berlin, Nr. Ms.or.oct.3369, France, Bibliotheque nationale de France, Nr. Turco 100, France, Bibliotheque nationale de France Nr. Turc 1131, USA Harvard Unıversity Houghton Library Nr. Ms.Turk. 8, SL. Âli Emîri Efendi Section Nr. 00584, SL, Âli Emîri Efendi Section Nr. 00585, SL. Âşîr Efendi Section Nr. 00238, SL. Ayasofya Section Nr. 03021, SL. Esâd Efendi Section Nr. 02175 / 004, SL. Efendi Section Nr. 02184, SL. Esad Efendi Section Nr. 02362/007, SL. Fatih Section Nr. 04234, SL. Fazıl Ahmet Paşa Section Nr. 01585, SL. Hacı Beşir Ağa Section Nr. 00459, SL. Hâcı Mahmud Efendi Section Nr. 04822, SL. Halet Efendi Section Nr. 00618, SL. Hüsrev Paşa Section Nr. 00327, SL. Hüsrev Paşa Section Nr. 00356, SL. Kılıç Ali Paşa Section Nr. 00780, SL. Lâleli Section Nr. 02012, SL. Lâleli Section Nr. 03647/014, SL. Nuru Osmaniye Section Nr. 03131, SL. Reisülküttab Section Nr. 00619, SL. Reşid Efendi Section Nr. 00618, SL. Reşid Efendi Section Nr. 00677, SL. Tercüman Section Nr. 00115, TPM. Bağdat Section Nr. B.194, R TPM. Revân Section Nr. R.1127, TPM. Revân Section Nr. R.1129, TPM. Revân Section Nr. R.1131, TPM. Revan Section Nr. R.1133, SHML Nr. 476, SHML Nr. 496, Konya-İZK. Nr. 13384, Konya-Karatay YAK. Nr. 474 / 1, İstanbul-YKSÇC. Nr. 1070, İMML. Atatürk Library Nr. K.1063, İMML. Atatürk Library Nr. K.1189, Ankara National Library Nr. 06 Mil Yz. A.965, Ankara National Library Nr.06 Mil Yz. 3202, Ankara National Library Nr. 06 Mil Yz. A.8119, Ankara National Library Nr. 06 Mil Yz. B.901, Ankara National Library Nr. 06 Hk 469/1, Amasya Bayezid City Public Library Nr.05 Ba 1628, Bursa İnebey Manuscript Library Nr. HO.1072, Bursa İnebey Manuscript Library Nr. GE.4959, Bursa İnebey Manuscript Library Nr. OR.1005., Ankara Turkish Historical Society Library, Nr. Y / 0323.

${ }^{41}$ Germany Staatsbibliothek, Berlin, Nr. Ms.or.oct.3369, SL. Âli Emîri Efendi Section Nr. 00584, SL. Âli Emîri Efendi Section Nr. 00585, SL. Âşîr Efendi Section Nr. 00238, SL. Esâd Efendi Section Nr. 02175 / 004, SL. Esad Efendi Section Nr. 02362/007, SL. Fatih Section Nr. 04234, SL. Hacı Beşir Ağa Section Nr. 00459, SL. Hâcı Mahmud Efendi Section Nr. 04822, SL. Halet Efendi Section Nr. 00618, SL. Reisülküttab Section Nr. 00619, SL. Reşid Efendi Section Nr. 00617, SL. Reşid Efendi Section Nr. 00634, SL. Reşid Efendi Section Nr. 00677, TPM. Bağdat Section Nr. B.194, TPM. Revân Section Nr. R.1128, SHML. Nr. 476, SHML. Nr. 497, Konya-Karatay YAK. Nr. 474/1, İstanbul-YKSÇC. Nr. 1070, İBL. Veliyüddün Efendi Nr. 2403, Ankara National Library Nr. 06 Mil Yz. A.965, Ankara National Library Nr. 06 Mil Yz. A.8119, Bursa İnebey Manuscript Library Nr. HO.1085, Bursa İnebey Manuscript Library Nr. OR.1005, Ankara Turkish Historical Society Library, Nr. Y / 0079-1. 


\begin{tabular}{|c|c|c|}
\hline France, Bibliotheque nationale de France. & Nr. Turc 493. & ? \\
\hline France, Bibliotheque nationale de France. & Nr. Turc 734. & $?$ \\
\hline France, Bibliotheque nationale de France. & Nr. Turc 1562. & $?$ \\
\hline France, Bibliotheque nationale de France. & Nr. Turc 520. & $?$ \\
\hline France, Bibliotheque nationale de France. & Nr. Turc 496. & $?$ \\
\hline Germany Staatsbibliothek, Berlin, & Ms.or.fol.4153 & $976 / 1568$ \\
\hline Germany Staatsbibliothek, Berlin, & Nr. Ms.or.oct.3369. & $1001 / 1592$ \\
\hline Germany Staatsbibliothek, Berlin, & Hs.Or.orct.876. & ? \\
\hline Germany Staatsbibliothek, Berlin, & Nr. Ms.Or.oct.1943. & $1030 / 1620$ \\
\hline Germany Staatsbibliothek, Berlin, & Nr. Hs.Or.oct.877. & ? \\
\hline Germany Staatsbibliothek, Berlin, & Nr. Ms.Or.quart.1482. & ? \\
\hline Germany Staatsbibliothek, Berlin, & Nr. Ms.or.fol.3332. & ? \\
\hline Germany Staatsbibliothek, Berlin, & Nr.Ms.Or.oct.985. & $?$ \\
\hline Austria Duchy Library Gotha Collection, & pt.216.Seetzen Nr. 8. & $?$ \\
\hline Spain, Madrid Biblioteca Nacional de Espana, & Nr. B.N.M. 12198. & ? \\
\hline $\begin{array}{ll}\text { Poland, Biblioteka } & \text { Uniwersytetu } \\
\text { Wroclawskiego, } & \\
\end{array}$ & Nr. M.1528. & $978 / 1570$ \\
\hline Britain, British Library, & Nr. Sloane 7871/1. & $?$ \\
\hline Britain, British Library, & Nr. Or.7290. & $?$ \\
\hline Britain, British Library, & Nr. Or.1130/1. & $1118 / 1707$ \\
\hline Britain, British Library, & Nr. Or.9865. & ? \\
\hline $\begin{array}{l}\text { Russia, Moscow Akademia Navk Naradov Azii } \\
\text { Enst. }\end{array}$ & Nr. C.828. & ? \\
\hline $\begin{array}{l}\text { Russia, Moscow Akademia Navk Naradov Azii } \\
\text { Enst. }\end{array}$ & Nr. B.727. & ? \\
\hline $\begin{array}{l}\text { Russia, Moscow Akademia Navk Naradov Azii } \\
\text { Enst. }\end{array}$ & Nr. B.754. & $?$ \\
\hline $\begin{array}{l}\text { Russia, Moscow Akademia Navk Naradov Azii } \\
\text { Enst. }\end{array}$ & Nr. B.714. & ? \\
\hline Vatican / Vatican Library. & Nr. 27. & ? \\
\hline Vatican / Vatican Library, & Nr.Vat.Turco 61. & $984 / 1576$ \\
\hline Egypt, Cairo National Library & $\begin{array}{l}\text { Nr. Tarih-i Türkî Halil Ağa } \\
30 \text {. }\end{array}$ & $?$ \\
\hline Egypt, Cairo National Library, & Nr. Tarih-i Türkî Talat 105. & $999 / 1590$ \\
\hline Egypt, Cairo National Library, & Nr. Tarih-i Türkî Talat 108. & $1003 / 1594$ \\
\hline Egypt, Cairo National Library, & Nr. M. Tarih-i Türkî 222. & ? \\
\hline Egypt, Cairo National Library, & Nr. Tarih-i Türkî Kula 37. & $?$ \\
\hline Egypt, Cairo National Library, & Nr. Tarih-i Türkî Talat 198. & $?$ \\
\hline Egypt, Cairo National Library, & Nr.Tarih-i Türkî Talat 138. & $?$ \\
\hline
\end{tabular}

\subsubsection{Copies Found in Domestic Collections}

The copies found in the domestic libraries are as follows:

\begin{tabular}{|l|l|l|}
\hline Collection that Contains the Copy & Archive Number & Copy Date Hijri/A.D. \\
\hline Süleymaniye Library, Ali Emîri Efendi Section, & Nr. 00584. & ? \\
\hline Süleymaniye Library, Ali Emîri Efendi Section & Nr. 00585. & $?$ \\
\hline Süleymaniye Library, Ali Emîri Section, & Nr. 01011. & $1031 / 1621$ \\
\hline Süleymaniye Library, Aşir Efendi Section, & Nr. 00238. & $1132 / 1719$ \\
\hline Süleymaniye Library, Ayasofya Section, & Nr. 03021. & $?$ \\
\hline Süleymaniye Library, Çelebi Abdullâh Section, & Nr. 00242. & $?$ \\
\hline Süleymaniye Library, Esad Efendi Section, & Nr. 01803-005. & $1052 / 1642$ \\
\hline Süleymaniye Library, Esad Efendi Section & Nr. 02172 & $?$ \\
\hline Süleymaniye Library, Esâd Efendi Section & Nr. 02175/004 & $1023 / 1614$ \\
\hline Süleymaniye Library, Esad Efendi Section, & Nr. 02184. & $?$ \\
\hline Süleymaniye Library, Esad Efendi Section & Nr. 02185 & $1127 / 1715$ \\
\hline Süleymaniye Library, Esad Efendi Section, & Nr. 02186. & $986 / 1578$ \\
\hline Süleymaniye Library, Esad Efendi Section, & Nr. 02362 / 007. & $?$ \\
\hline
\end{tabular}




\begin{tabular}{|c|c|c|}
\hline Süleymaniye Library, Fatih Section, & Nr. 04234. & ? \\
\hline Süleymaniye Library, Fazıl Ahmet Paşa Section, & Nr. 01585. & $1000 / 1591$ \\
\hline Süleymaniye Library, Hacı Beșir Ağa Section & Nr. 00459 & $981 \mathrm{H} / 1573$ \\
\hline $\begin{array}{l}\text { Süleymaniye Library, Hacı Mahmud Efendi } \\
\text { Section }\end{array}$ & Nr. 04822 & $1018 / 1609$ \\
\hline $\begin{array}{l}\text { Süleymaniye Library, Hacı Mahmud Efendi } \\
\text { Section }\end{array}$ & Nr. 04857. & $1009 / 1600$ \\
\hline Süleymaniye Library, Halet Efendi Section, & Nr. 00618. & ? \\
\hline Süleymaniye Library, Halet Efendi Section, & Nr. 00036 / 008. & ? \\
\hline Süleymaniye Library, Hüsrev Paşa Section, & Nr. 00327. & ? \\
\hline Süleymaniye Library, Hüsrev Paşa Section, & Nr. 00356. & $1001 / 1602$ \\
\hline Süleymaniye Library, Kılıç Ali Paşa Section, & Nr. 00780. & $1020 / 1611$ \\
\hline Süleymaniye Library, Laleli Section, & Nr. 02012. & ? \\
\hline Süleymaniye Library, Laleli Section, & Nr. 03647 / 014. & ? \\
\hline $\begin{array}{l}\text { Süleymaniye Library, Murad Molla (M.Arif } \\
\text { Efendi) Section, }\end{array}$ & Nr. 00184. & $994 / 1585$ \\
\hline Süleymaniye Library, Nuru Osmaniye Section, & Nr. 03131. & $980 / 1572$ \\
\hline Süleymaniye Library, Nuru Osmaniye Section, & Nr. 03159. & $1100 / 1689$ \\
\hline Süleymaniye Library, Pertevniyal Section, & Nr. 00835 / 002. & $1140 / 1728$ \\
\hline Süleymaniye Library, Reisülküttab Section & Nr. 00619. & ? \\
\hline Süleymaniye Library, Reşid Efendi Section & Nr. 00617 & ? \\
\hline Süleymaniye Library, Reşid Efendi Section, & Nr. 00618. & ? \\
\hline Süleymaniye Library, Reşid Efendi Section, & Nr. 00634. & ? \\
\hline Süleymaniye Library, Reşid Efendi Section, & Nr. 00677. & $980 / 1572$ \\
\hline Süleymaniye Library, Tercüman Section, & Nr. 00115 & ? \\
\hline Topkapı Palace Museum, Bağdat Section, & Nr. B.194. & ? \\
\hline Topkapı Palace Museum, Bağdat Section, & Nr. B.195. & ? \\
\hline Topkapı Palace Museum, Medine Section, & Nr. M.526. & ? \\
\hline Topkapı Palace Museum, Revan Section, & Nr. R.1127. & $1002 / 1593$ \\
\hline Topkap1 Palace Museum, Revan Section, & Nr. R.1128. & $1002 / 1593$ \\
\hline Topkapı Palace Museum, Revan Section, & Nr. R.1129. & 1144 / 1732 \\
\hline Topkapı Palace Museum, Revan Section, & Nr. R.1130. & ? \\
\hline Topkapı Palace Museum, Revan Section, & Nr. R.1131. & $?$ \\
\hline Topkapı Palace Museum, Revan Section, & Nr. R.1132. & $997 / 1588$ \\
\hline Topkap1 Palace Museum, Revan Section, & Nr. R.1133. & ? \\
\hline Sadberk Hanım Museum Collection, & Nr. 476. & ? \\
\hline Sadberk Hanım Museum Collection, & Nr. 496. & ? \\
\hline Sadberk Hanım Museum Collection, & Nr. 497. & ? \\
\hline Konya - İzzet Koyunoğlu Library, & Nr. 13383. & $995 / 1586$ \\
\hline Konya - İzzet Koyunoğlu Library, & Nr. 13384. & $1029 / 1619$ \\
\hline Konya-Karatay Yusuf Ağa Library, & Nr. $474 / 1$. & ? \\
\hline Kastamonu City Public Library, & Nr. 37 Hk. $2364 / 1$. & $1031 / 1621$ \\
\hline Kastamonu City Public Library, & Nr. 37 Hk 1962. & $993 / 1584$ \\
\hline Diyarbakır City Public Library, & Nr. 845. & $1072 / 1660$ \\
\hline İzmir National Library, & Nr. 928. & ? \\
\hline İstanbul-Yapı Kredi Sermet Çifter Collection, & Nr. 1070 & ? \\
\hline İstanbul Bayezıd Library, & Nr. 5268 / 38. & $991 / 1583$ \\
\hline $\begin{array}{l}\text { İstanbul Bayezıd Library, Veliyüddün Efendi } \\
\text { Section, }\end{array}$ & Nr. 2403. & $1133 / 1720$ \\
\hline $\begin{array}{l}\text { İstanbul Metropolitan Municipality Library, } \\
\text { Atatürk Library, }\end{array}$ & Nr. K.1063. & ? \\
\hline $\begin{array}{l}\text { İstanbul Metropolitan Municipality Library, } \\
\text { Atatürk Library, }\end{array}$ & Nr. K.1189. & ? \\
\hline Ankara National Library, & Nr. 06 Mil Yz. A.45. & 1048 / 1638 \\
\hline Ankara National Library, & Nr. 06 Mil Yz. A.965. & 1042 / 1632 \\
\hline Ankara National Library, & Nr. 06 Mil Yz. 3035 / 1. & ? \\
\hline Ankara National Library, & Nr. 06 Mil Yz. 3164. & ? \\
\hline
\end{tabular}




\begin{tabular}{|l|l|l|}
\hline Ankara National Library & Nr. 06 Mil Yz. 3202. & $?$ \\
\hline Ankara National Library, & Nr. 06 Mil Yz. A.3261. & $1001 / 1592$ \\
\hline Ankara National Library & Nr. 06 Mil Yz. A.8119. & 1060 / 1650 \\
\hline Ankara National Library, & Nr. 06 Mil Yz. B.901. & $?$ \\
\hline Ankara National Library, & Nr. 06 Hk 469/1. & $?$ \\
\hline Amasya Bayezıd City Public Library, & Nr.05 Ba 1628. & $?$ \\
\hline Bursa İnebey Manuscript Library, & Nr. HO.1072. & $?$ \\
\hline Bursa İnebey Manuscript Library, & Nr. HO.1085. & $?$ \\
\hline Bursa İnebey Manuscript Library, & Nr. GE.4959. & $?$ \\
\hline Bursa İnebey Manuscript Library, & Nr. OR.1005. & $1006 / 1597$ \\
\hline Ankara Turkish Historical Society Library, & Nr. Y / 0079-1. & $?$ \\
\hline Ankara Turkish Historical Society Library, & Nr. Y / 0323. & $?$ \\
\hline
\end{tabular}

\subsubsection{Printed Copies}

\begin{tabular}{|l|l|l|}
\hline Collection that Contains the Copy & Archive Number & Copy Date Hijri/A.D. \\
\hline University of Toronto Library, & Dr.481/M.1862. & $1279 / 1862$ \\
\hline University of Toronto Library, & Nr. Dr.481/M.1873. & $1290 / 1873$ \\
\hline
\end{tabular}

\section{Conclusion}

Known with the epithet Ramazân-zâde, Nişâncı Mehmed Paşa, who was a statesman and a historian of the $16^{\text {th }}$ century, wrote a book known with his own name and written as a piece of summary general history. Târîh-i Nişâncı Paşa was written as a summary in order for giving answers to questions simply, and preserving the pieces of information easily. In the first chapter, where the history of the prophets were told, the anecdotes of the prophets were mentioned and the information about time intervals among all of the prophets was given in years. While the era of the Prophet Muhammad was mentioned in a chronological manner, the (first) four khalifas were recorded grounding on their bloodlines and mentioning about how they were called, dates of birth and death, their caliphate durations, their lifetimes, and their important contributions. The chapter that mentioned about the Umayyad, Abbasid, Fatimid, Ayyubid, Mameluke, and Circassian states, was completely comprised of genealogical pieces of information. The third chapter discussed the events starting from the foundation of the Ottoman State until the political murder of Bayezid, the son of Suleiman the Magnificent, in Kazvin. The charities and benefactions of each sultan, though brief, the biographies of high state officials, ulema (pundits), and sheiks were given. This chapter is the most voluminous part of the book. In this part, it is particularly obvious that Ramazân-zâde used a more systematical narration after the era of the Bayezid II. Adding a partial elaborateness to this systematic narration after the era of Suleiman the Magnificent, the book became more systematical in later parts. In the fourth chapter, the pieces of information were mentioned about the durations of the reigns, total lifetimes, genealogical information, activities that are important for the history, and first implementations of the times of the emperors of Pisdadi, Keyani, Eskani, and Sassanids.

Together with the newly discovered copies, there are 76 copies of this book in domestic collections and 40 in international collections. The high number of its copies is a demonstration of the fact that this book was quite popular in its time. In this respect, this book can be compared to today's easy-to-understand popular history books, which are written through short questions and answers in an attempt to be read by large masses. Additionally, this excessive number of copies is an indicator of that Târîh-i Nişâncı Paşa had been transfromed into a hand book or a pocket book. However, this fact not only prevents us from reaching to the original manuscript but also includes some negative influences such as distancing from its original version.

In this study, firstly, certain pieces of information were presented about the life of Ramazân-zâde and general information was given about the publication reason and content of the book named Târîh-i Nişânc1 Paşa. Subsequently, detailed introduction and description were 
made about the locations of the collections, archive numbers, and copying dates of the 116 copies determined in domestic and international libraries. By means of introduction and description activity, it was attempted to contribute to the reorganizing of the cataloging of the copies in the domestic and international libraries. In addition to that, with the detection, introduction and description of the copies, whose number is high, the disorganization of the copies is attempted to be eliminated to some extent. This study was put at the disposal of the history researchers with the author-book introduction and identification.

\section{Bibliography}

\section{Manuscript Sources}

Ahmed Resmi Efendi, Halifetü'r-Rüesâ, İstanbul 1269.

İbrahim Peçevi Efendi, Peçevi Târîhi, Unıversity of Toronto DR 511 P33 V.1.

Ramazân-zâde, Târîh-i Nişâncı Paşa, Unıversity of Toronto Library Nr. Dr.481/M.1873.

Ramazân-zâde, Târîh-i Nişâncı Paşa, Unıversity of Toronto Library, Nr.Dr.481/M.1862.

Ramazân-zâde, Târîh-i Nişâncı Paşa, Germany Staatsbibliothek, Berlin, Ms.or.fol.4153.

Ramazân-zâde, Târîh-i Nişâncı Paşa, France, Bibliotheque nationale de France.Nr. Turco 96.

Ramazân-zâde, Târîh-i Nişâncı Paşa, Germany Staatsbibliothek, Berlin, Nr. Ms.or.oct.3369.

Ramazân-zâde, Târîh-i Nişâncı Paşa, France, Bibliotheque nationale de France. Nr. Turco 100.

Ramazân-zâde, Târîh-i Nişâncı Paşa, ABD Harvard Unıversity Houghton Library Nr. Ms. Turk. 8.

Ramazân-zâde, Târîh-i Nişâncı Paşa, Süleymaniye Library Âli Emîri Efendi Section, Nr. 00584.

Ramazân-zâde, Târîh-i Nişâncı Paşa, Süleymaniye Library Âli Emîri Efendi Section Nr. 00585.

Ramazân-zâde, Târîh-i Nişâncı Paşa, Süleymaniye Library Âli Emîri Section, Nr. 01011.

Ramazân-zâde, Târîh-i Nişâncı Paşa, Süleymaniye Library Âşîr Efendi Section, Nr. 00238.

Ramazân-zâde, Târîh-i Nişâncı Paşa, Süleymaniye Library-Ayâsofya Section, Nr. 03021.

Ramazân-zâde, Târîh-i Nişâncı Paşa, Süleymaniye Library Çelebi Abdullâh Section, Nr. 00242.

Ramazân-zâde, Târîh-i Nişâncı Paşa, Süleymaniye Library Esâd Efendi Section, Nr. 01803005.

Ramazân-zâde, Târîh-i Nişâncı Paşa, Süleymaniye Library Esâd Efendi Section Nr. 02172.

Ramazân-zâde, Târîh-i Nişâncı Paşa, Süleymaniye Library Esâd Efendi Section Nr. 02175 / 004.

Ramazân-zâde, Târîh-i Nişâncı Paşa, Süleymaniye Library Esâd Efendi Section, Nr. 02184.

Ramazân-zâde, Târîh-i Nişâncı Paşa, Süleymaniye Library Esâd Efendi Section Nr. 02185

Ramazân-zâde, Târîh-i Nişâncı Paşa, Süleymaniye Library Esad Efendi Section, Nr. 02186.

Ramazân-zâde, Târîh-i Nişâncı Paşa, Süleymaniye Library Esad Efendi Section, Nr. 02362 / 007.

Ramazân-zâde, Târîh-i Nişâncı Paşa, Süleymaniye Library Fatih Section, Nr. 04234. 
Ramazân-zâde, Târîh-i Nişâncı Paşa, Süleymaniye Library Fazıl Ahmet Paşa Section, Nr. 01585.

Ramazân-zâde, Târîh-i Nişâncı Paşa, Süleymaniye Library Hacı Beşir Ağa Section Nr. 00459.

Ramazân-zâde, Târîh-i Nişâncı Paşa, Süleymaniye Library Hacı Mahmud Efendi Section Nr. 04822.

Ramazân-zâde, Târîh-i Nişâncı Paşa, Süleymaniye Library Hacı Mahmud Efendi Section Nr. 04857.

Ramazân-zâde, Târîh-i Nişâncı Paşa, Süleymaniye Library Halet Efendi Section, Nr. 00618.

Ramazân-zâde, Târîh-i Nişâncı Paşa, Süleymaniye Library Hâlet Efendi Section, Nr. 00036 / 008.

Ramazân-zâde, Târîh-i Nişâncı Paşa, Süleymaniye Library Hüsrev Paşa Section, Nr. 00327.

Ramazân-zâde, Târîh-i Nişâncı Paşa, Süleymaniye Library Hüsrev Paşa Section, Nr. 00356.

Ramazân-zâde, Târîh-i Nişâncı Paşa, Süleymaniye Library Kılıç Ali Paşa Section, Nr. 00780.

Ramazân-zâde, Târîh-i Nişâncı Paşa, Süleymaniye Library Lâleli Section, Nr. 02012.

Ramazân-zâde, Târîh-i Nişâncı Paşa, Ramazan-zâde, Târîh-i Nişâncı Paşa, Süleymaniye Library Lâleli Section, Nr. 03647 / 014.

Ramazân-zâde, Târîh-i Nişâncı Paşa, Süleymaniye Library Murad Molla (M.Arif Efendi) Section, Nr. 00184.

Ramazân-zâde, Târîh-i Nişâncı Paşa, Süleymaniye Library Nuru Osmaniye Section, Nr. 03131.

Ramazân-zâde, Târîh-i Nişâncı Paşa, Süleymaniye Library Nuru Osmaniye Section, Nr. 03159.

Ramazân-zâde, Târîh-i Nişâncı Paşa, Süleymaniye Library Pertevniyal Section, Nr. 00835 / 002.

Ramazân-zâde, Târîh-i Nişâncı Paşa, Ramazan-zâde, Târîh-i Nişâncı Paşa, Süleymaniye Library Reisülküttab Section Nr. 00619.

Ramazân-zâde, Târîh-i Nişâncı Paşa, Süleymaniye Library Reşid Efendi Section Nr. 00617.

Ramazân-zâde, Târîh-i Nişâncı Paşa, Süleymaniye Library Reşid Efendi Section, Nr. 00618.

Ramazân-zâde, Târîh-i Nişânc1 Paşa, Süleymaniye Library Reşid Efendi Section, Nr. 00634.

Ramazân-zâde, Târîh-i Nişâncı Paşa, Süleymaniye Library Reşid Efendi Section, Nr. 00677.

Ramazân-zâde, Târîh-i Nişâncı Paşa, Süleymaniye Library Tercüman Section, Nr. 00115

Ramazân-zâde, Târîh-i Nişâncı Paşa, Topkapı Palace Museum Bağdat Section, Nr. B.194.

Ramazân-zâde, Târîh-i Nişâncı Paşa, Ramazan-zâde, Târîh-i Nişâncı Paşa, Topkapı Palace Museum Bağdat Section, Nr. B.195.

Ramazân-zâde, Târîh-i Nişâncı Paşa, Topkapı Palace Museum Medine Section, Nr. M.526.

Ramazân-zâde, Târîh-i Nişâncı Paşa, Topkapı Palace Museum Revân Section, Nr. R.1127.

Ramazân-zâde, Târîh-i Nişâncı Paşa, Topkapı Palace Museum Revân Section, Nr. R.1128.

Ramazân-zâde, Târîh-i Nişâncı Paşa, Topkapı Palace Museum Revân Section, Nr. R.1129.

Ramazân-zâde, Târîh-i Nişâncı Paşa, Topkapı Palace Museum Revân Section, Nr. R.1130.

Ramazân-zâde, Târîh-i Nişâncı Paşa, Topkapı Palace Museum Revân Section, Nr. R.1131. 
Ramazân-zâde, Târîh-i Nişâncı Paşa, Topkapı Palace Museum Revân Section, Nr. R.1132.

Ramazân-zâde, Târîh-i Nişâncı Paşa, Topkapı Palace Museum Revân Section, Nr. R.1133.

Ramazân-zâde, Târîh-i Nişâncı Paşa, Sadberk Hanım Museum Collection, Nr. 476.

Ramazân-zâde, Târîh-i Nişâncı Paşa, Sadberk Hanım Museum Collection, Nr. 496.

Ramazân-zâde, Târîh-i Nişâncı Paşa, Sadberk Hanım Museum Collection, Nr. 497.

Ramazân-zâde, Târîh-i Nişâncı Paşa, Konya - İzzet Koyunoğlu Library, Nr. 13383.

Ramazân-zâde, Târîh-i Nişâncı Paşa, Konya - İzzet Koyunoğlu Library, Nr. 13384.

Ramazân-zâde, Târîh-i Nişâncı Paşa, Konya-Karatay Yusuf Ağa Library, Nr. 474 / 1.

Ramazân-zâde, Târîh-i Nişâncı Paşa, Kastamonu City Public Library, Nr. 37 Hk. 2364 /1.

Ramazân-zâde, Târîh-i Nişâncı Paşa, Kastamonu City Public Library, Nr. 37 Hk 1962.

Ramazân-zâde, Târîh-i Nişâncı Paşa, Diyarbakır City Public Library, Nr. 845.

Ramazân-zâde, Târîh-i Nişâncı Paşa, İzmir National Library, Nr. 928.

Ramazân-zâde, Târîh-i Nişâncı Paşa, İstanbul-Yapı Kredi Sermet Çifter Collection, Nr. 1070.

Ramazân-zâde, Târîh-i Nişâncı Paşa, İstanbul Bayezıd Library, Nr. 5268 / 38.

Ramazân-zâde, Târîh-i Nişâncı Paşa, İstanbul Bayezıd Library Veliyüddün Efendi, Nr. 2403.

Ramazân-zâde, Târîh-i Nişâncı Paşa, İstanbul Metropolitan Municipality Library Atatürk Library, Nr. K.1063.

Ramazân-zâde, Târîh-i Nişâncı Paşa, İstanbul Metropolitan Municipality Library Atatürk Library, Nr. K.1189.

Ramazân-zâde, Târîh-i Nişâncı Paşa, Ankara National Library, Nr. 06 Mil Yz. A.45.

Ramazân-zâde, Târîh-i Nişâncı Paşa, Ankara National Library, Nr. 06 Mil Yz. A.965.

Ramazân-zâde, Târîh-i Nişâncı Paşa, Ankara National Library, Nr. 06 Mil Yz. 3035 / 1.

Ramazân-zâde, Târîh-i Nişâncı Paşa, Ankara National Library, Nr. 06 Mil Yz. 3164.

Ramazân-zâde, Târîh-i Nişâncı Paşa, Ankara National Library, Nr. 06 Mil Yz. 3202.

Ramazân-zâde, Târîh-i Nişâncı Paşa, Ankara National Library, Nr. 06 Mil Yz. A.3261.

Ramazân-zâde, Târîh-i Nişâncı Paşa, Ankara National Library, Nr. 06 Mil Yz. A.8119.

Ramazân-zâde, Târîh-i Nişâncı Paşa, Ankara National Library, Nr. 06 Mil Yz. B.901.

Ramazân-zâde, Târîh-i Nişâncı Paşa, Ankara National Library, Nr. 06 Hk 469/1.

Ramazân-zâde, Târîh-i Nişâncı Paşa, Amasya Bayezıd City Public Library, Nr.05 Ba 1628.

Ramazân-zâde, Târîh-i Nişâncı Paşa, Bursa İnebey Manuscript Library, Nr. HO.1072.

Ramazân-zâde, Târîh-i Nişâncı Paşa, Bursa İnebey Manuscript Library, Nr. HO.1085.

Ramazân-zâde, Târîh-i Nişâncı Paşa, Bursa İnebey Manuscript Library, Nr. GE.4959.

Ramazân-zâde, Târîh-i Nişâncı Paşa, Bursa İnebey Manuscript Library, Nr. OR.1005.

Ramazân-zâde, Târîh-i Nişâncı Paşa, Ankara Turkish Historical Society Library, Nr. Y/0079-1.

Ramazân-zâde, Târîh-i Nişâncı Paşa, Ankara Turkish Historical Society Library, Nr. Y/0323. 


\section{Research-Examination Books}

Arslan, Mehmet, Mehmed Cemâleddîn, Osmanlı Tarih ve Müverrihleri-Âyine-i Zurefâ, Kitabevi Yay., İstanbul 2003.

Aydemir, Mehmed Süreyya, Sicil-i Osmanî, Cilt III, Tarih Vakfi Yurt Yay., İstanbul 1996.

Bayrak, Orhan, Osmanlı Tarihi Yazarları, Milenyum Yay. İstanbul 2002.

Balc1, Rüştü, Keşfü'z-Zunûn, An Esâmi'l-Kütübî ve'l-Fünûn (lit. Removing the Doubts from the Names of the Books and Sciences),Cilt I,Tarih Vakfi Yurt Yay. İstanbul 2007.

Baykal, Bekir Sitkı, Peçevi Tarihi, Cilt I, Kültür Bakanlığı Yay., Ankara 1999.

Donuk, Suat, Hadâiku'l-hakâ'ik fì Tekmileti'ş-Şakâ'ik, Nev'î-zâde Atâyînin Şekâ'ik Zeyli, Inceleme-Tenkitli Metin, Edt. Örs Derya, Cilt I, Türkiye Yazma Eserler Kurumu Başkanlığı, İstanbul 2017.

Özcan, Abdülkadir, “Mehmed Çelebi-Ramazân-zâde”, Diyânet İslâm Ansiklopedisi, Türkiye Diyânet Vakfi Yay., Cilt 28, İstanbul 2003, 449-450.

Tahir, Bursalı Mehmed, Osmanlı Müellifleri,Cilt III, İstanbul 1975.

\section{Internet Addresses}

http://hollis.harvard.edu/primo_library/libweb/action/dlSearch.do?institution=HVD\&vid=HVD \&tab=everything\&search_scope=everything\&mode=Basic\&onCampus=false\&displayM ode=full\&highlight=true\&query=any\%2Ccontains\%2CMEHMED+PA\%C5\%9EA+N\%C 4\%B0\%C5\%9EANCI\&displayField=all\&pcAvailabiltyMode=true\&bulkSize=30 (Last Visited: 09.06.2015)

https://archivesetmanuscrits.bnf.fr/ark:/12148/cc934918 (Last Visited: 06.10. 2015)

https://archivesetmanuscrits.bnf.fr/ark:/12148/cc940719 (Last Visited: 06.11.2015)

https://archivesetmanuscrits.bnf.fr/ark:/12148/cc938158 (Last Visited: 06.12.2015)

https://archivesetmanuscrits.bnf.fr/ark:/12148/cc938180 (Last Visited: 06.13.2015)

https://archivesetmanuscrits.bnf.fr/ark:/12148/cc93328b (Last Visited: 06.14.2015)

https://archivesetmanuscrits.bnf.fr/ark:/12148/cc938464 (Last Visited: 06.15.2015)

https://archivesetmanuscrits.bnf.fr/ark:/12148/cc931280 (Last Visited: 06.16.2015)

https://archivesetmanuscrits.bnf.fr/ark:/12148/cc929838 (Last Visited: 06.17.2015)

https://archivesetmanuscrits.bnf.fr/ark:/12148/cc929821 (Last Visited: 06.18.2015)

https://archivesetmanuscrits.bnf.fr/ark:/12148/cc92605 (Last Visited: 06.19.2015)

http://topkapisarayi.gov.tr/tr/yazma-

eserler?field_adi_value=TEVK\%C4\%B0\%20\%20MEHMED\%20PA\%C5\%9EA\&field_b olum_value=MED\%C4\%B0NE\&field_ciltsayfa_value=\&field_dil_value=\&field_envant er_value=\%20TSMK\%20M.526\&field_konu_value=\&field_yayintarihi_value=\&field_y azar_value $=\&$ field_yazituru_value $=\& p a g e=8$ (Last Visited: 10.20 .2015$)$

http://topkapisarayi.gov.tr/tr/yazma-eserler?field_adi_value=TAR\%C4\%B0H\%C4\%B0\%20N\%C4\%B0\%C5\%9EANCI\%20MEHMED\%20PA\%C5\%9EA\&field_bolu m_value $=$ BA\%C4\%9EDAT\&field_ciltsayfa_value $=\&$ field_dil_value $=\&$ field_envanter_v alue=\%20\%20TMSK\%20B.194\&field_konu_value=\&field_yayintarihi_value=\&field_ya zar_value $=\&$ field_yazituru_value $=\&$ page $=4$ (Last Visited: 10.20. 2015) 
http://topkapisarayi.gov.tr/tr/yazma-eserler?field_adi_value=TAR\%C4\%B0H\%C4\%B0\%20TEVK\%C4\%B0\&field_bolum_value=BA\%C4\%9EDAT\&field_ciltsayfa_ value $=\&$ field_dil_value $=\&$ field_envanter_value $=\% 20 \% 20$ TMSK\%20B.194\&field_konu

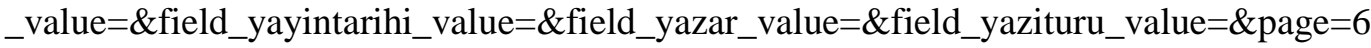
(Last Visited: 11.01.2015)

http://topkapisarayi.gov.tr/tr/yazma-eserler?field_adi_value=TAR\%C4\%B0H-

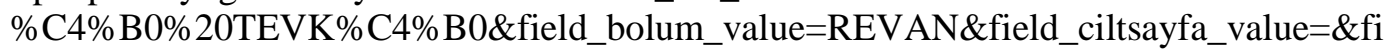
eld_dil_value=\&field_envanter_value=\%20\%20TMSK\%20R.1129\&field_konu_value= \&field_yayintarihi_value $=\& f i e l d \_y a z a r \_v a l u e=\& f i e l d \_y a z i t u r u \_v a l u e=\& p a g e=3 \quad$ (Last Visited: 11.10 .2015$)$

http://topkapisarayi.gov.tr/tr/yazma-eserler?field_adi_value=TAR\%C4\%B0H\%C4\%B0\%20TEVK\%C4\%B0\&field_bolum_value=BA\%C4\%9EDAT\&field_ciltsayfa_ value $=\&$ field_dil_value $=\&$ field_envanter_value $=\% 20 \% 20$ TMSK\%20B.194\&field_konu

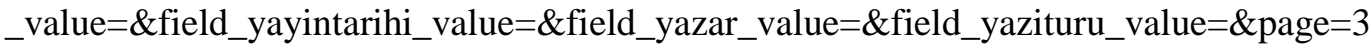
(Last Visited: 11.30.2015)

http://topkapisarayi.gov.tr/tr/yazma-eserler?field_adi_value=TAR\%C4\%B0H-

\%C4\%B0\%20TEVK\%C4\%B0\&field_bolum_value=BA\%C4\%9EDAT\&field_ciltsayfa_ value $=\&$ field_dil_value $=\&$ field_envanter_value $=\% 20 \% 20$ TMSK\%20B.194\&field_konu _value $=\&$ field_yayintarihi_value $=\&$ field_yazar_value $=\&$ field_yazituru_value $=\& p a g e=4$ (Last Visited: 11.30.2015)

http://topkapisarayi.gov.tr/tr/yazma-eserler?field_adi_value=TAR\%C4\%B0H\%C4\%B0\%20TEVK\%C4\%B0\&field_bolum_value=REVAN\&field_ciltsayfa_value=\&fi eld_dil_value $=\&$ field_envanter_value $=\% 20 \% 20 \mathrm{TMSK} \% 20 \mathrm{R} .1129 \&$ field_konu_value $=$ \&field_yayintarihi_value $=\& f i e l d \_y a z a r \_v a l u e=\& f i e l d \_y a z i t u r u \_v a l u e=\& p a g e=5 \quad$ (Last Visited: 12.05.2015 )

http://www.yazmalar.gov.tr/eser/tar\%C3\%AEh-i-tevkii/92715 (Last Visited: 12.05.2015 )

http://www.yazmalar.gov.tr/eser/tar\%C3\%AEh-i-tevkii/92717 (Last Visited: 12.08.2015 )

http://www.yazmalar.gov.tr/eser/tar\%C3\%AEh-i-tevkii/92721 (Last Visited: 12.10.2015 )

http://www.yazmalar.gov.tr/basit-

arama/sayfa/1?q=Ni\%C5\%9Fanc\%C4\%B1\%20Mehmed\%20Pa\%C5\%9Fa (Last Visited: 09.25.2015 )

http://www.yazmalar.gov.tr/basit-

arama/sayfa/14?q=Ni\%C5\%9Fanc\%C4\%B1\%20Mehmed\%20Pa\%C5\%9Fa (Last Visited: 09.25.2015 )

http://www.yazmalar.gov.tr/eser/tar\%C3\%AEh-i-muntahab-lil-fehm-i-akrab/115205 (Last Visited: 09.25.2015 )

http://www.yazmalar.gov.tr/eser/tar\%C3\%AEh-i-muntehab-lil-fehm-i-akrab/20520 ～(Last Visited: 12.18.2015 )

http://www.yazmalar.gov.tr/eser/tar\%C3\%AEh-i-\%C3\%82l-i-osman/61026 (Last Visited: 12.05.2015 )

http://www.yazmalar.gov.tr/eser/tar\%C3\%AEh-i-kostantiniye/61252 (Last Visited: 12.05.2015 )

http://www.yazmalar.gov.tr/eser/menakib-i-selat\%C3\%AEn-i-al\%C3\%AE-osman/86269 (Last Visited: 12.05.2015 )

http://www.yazmalar.gov.tr/eser/tar\%C3\%AEh-i-tevkii/92701 (Last Visited: 12.05.2015 ) 
http://www.yazmalar.gov.tr/eser/tar\%C3\%AEh-i-tevkii/92696 (Last Visited: 11.30.2015 ) http://www.yazmalar.gov.tr/eser/tar\%C3\%AEh-i-tevkii/92711 (Last Visited: 11.30.2015 ) http://www.yazmalar.gov.tr/eser/tar\%C3\%AEh-i-tevkii/92713 (Last Visited: 11.30.2015 ) http://www.yazmalar.gov.tr/eser/tar\%C3\%AEh-i-tevkii/92715 (Last Visited: 11.30.2015 ) http://www.yazmalar.gov.tr/eser/tar\%C3\%AEh-i-tevkii/92717 (Last Visited:11. 30.2015 ) http://www.yazmalar.gov.tr/eser/tar\%C3\%AEh-i-tevkii/92721 (Last Visited:11. 30.2015 ) http://www.yazmalar.gov.tr/eser/tar\%C3\%AEh-i-tevkii/92724 (Last Visited:11. 30.2015 ) http://www.yazmalar.gov.tr/eser/tar\%C3\%AEh-i-tevkii/92727 (Last Visited:11. 30.2015 ) http://www.yazmalar.gov.tr/eser/tar\%C3\%AEh-i-tevkii/92728 (Last Visited:11. 30.2015 ) http://www.yazmalar.gov.tr/eser/tar\%C3\%AEh-i-nisanci-pasa/104173 (Last Visited: 11.30.2015) http://www.yazmalar.gov.tr/eser/tar\%C3\%AEh-i-nisanci-pasa/104174 (Last Visited: 11.30.2015) http://www.yazmalar.gov.tr/eser/tar\%C3\%AEh-i-nisanci-pasa/104175 (Last Visited: 11.30.2015) http://www.yazmalar.gov.tr/eser/nisanci-pasa-tarihi/207703 (Last Visited: 12.15.2015 ) http://www.yazmalar.gov.tr/eser/tar\%C3\%AEh-i-kostantiniye/61252 (Last Visited: 12.18.2015 ) http://www.yazmalar.gov.tr/eser/tar\%C3\%AEh-i-nisanci-pasa/100817 (Last Visited: 12.20.2015) http://www.yazmalar.gov.tr/eser/tar\%C3\%AEh-i-muntahab-lil-fehm-i-akrab/121562 ～(Last Visited: 12.20.2015 )

http://www.yazmalar.gov.tr/eser/tar\%C3\%AEh-i-muntahab-lil-fehm-i-akrab/115203 ～(Last Visited: 12.22.2015 )

http://www.yazmalar.gov.tr/eser/tar\%C3\%AEh-i-muntahab-lil-fehm-i-akrab/115625 (Last Visited: 12.24.2015)

http://www.yazmalar.gov.tr/eser/tevar\%C3\%AEh-i-nisanci/136499 (Last Visited: 12.20.2015 )

http://www.yazmalar.gov.tr/eser/tar\%C3\%AEh-i-muntehab-lil-fehm-i-akrab/136341 （Last Visited: 12.20.2015 )

http://www.yazmalar.gov.tr/eser/tevar\%C3\%AEh-i-nisanci/136499 (Last Visited: 12.28.2015 )

http://dijital

kutuphane.mkutup.gov.tr/tr/manuscripts/catalog/details/335670?SearchType=2(Last Visited: 12.25.2015 )

http://dijital-kutuphane.mkutup.gov.tr/tr/manuscripts/catalog/details/322594?Search Type=2 (Last Visited: 12.31.2015)

http://dijital-kutuphane.mkutup.gov.tr/tr/manuscripts/catalog/details/335670?Search Type=2 (Last Visited: 12.25.2015 )

http://dijital-kutuphane.mkutup.gov.tr/tr/manuscripts/catalog/details/254819?Search $\quad$ Type=2 (Last Visited: 12.31.2015)

http://dijital-kutuphane.mkutup.gov.tr/tr/manuscripts/catalog/details/324710?Search $\quad$ Type=2 (Last Visited: 12.30.2015)

http://dijital-kutuphane.mkutup.gov.tr/tr/manuscripts/catalog/details/332297?Search Type=2 (Last Visited: 12.2015 ) 
http://dijital-kutuphane.mkutup.gov.tr/tr/manuscripts/catalog/details/332927?Search $\quad$ Type=2 (Last Visited: 12.28.2015)

http://dijital-kutuphane.mkutup.gov.tr/tr/manuscripts/catalog/details/344882?Search Type=2 (Last Visited: 12.25.2015 )

http://kutuphane.ttk.gov.tr/details?id=399154\&materialType=YE\&query=Ni\%C5\%9Fanc\%C4 \%B1+Mehmed+Pa\%C5\%9Fa (Last Visited: 01.10.2016)

http://kutuphane.ttk.gov.tr/details?id=399500\&materialType=YE\&query=Ni\%C5\%9Fanc\%C4 \%B1+Mehmed+Pa\%C5\%9Fa (Last Visited: 01.10.2016) 